\section{Calmodulin and eukaryote evolution}

SIR-The ubiquity of calmodulin is primarily evidence for the ubiquity of calmodulin, not for evolution' - even if found in an "ancestral type". You say in your "Periodic extinctions undermined" that cautious people will insist that there is as yet only circumstantial evidence that the impact caused the extinction. Would that such caution extended to biologists! Let us remind ourselves, as Schopenhauer never tires of reminding us, that one cannot make aetiological deductions from morphology.

43 Emanuel House,

Frank W. Cousins

18 Rochester Row,

London SW1, UK

Nature $315,720(1985)$

2. Nature 315, 627 (1985)

\section{Ragweed in China}

SIR-Yeh has recently reported that ragweed hay fever is not present in China ${ }^{1}$. This is, of course, understandable if ragweed plants are not found there, which Yeh assumed.

The Chinese botanical literature ${ }^{2.3}$, however, reports that ragweed (Ambrosia) is not only present in China, but present in abundance $-A$. artemisiifolia in the reaches of the Changiiang (Yangtze) River and along roadsides there and $\boldsymbol{A}$. trifida along village paths and riverbanks in northeastern China.

The disparity between the reported absence of ragweed hay fever and the presence of ragweed plants is puzzling, but not unique. It is analogous to the puzzle of timothy grass (Phleum pratense) ${ }^{4}$. Timothy is an important allergen in the West and, like ragweed in America, is a common cause of hay fever. Timothy is abundant along roadsides and in fields throughout China ${ }^{5}$, but, like ragweed, is not reported to have clinical importance there'.

Finally, Broder et al. ${ }^{6}$, in a sample of 6,563 Americans, found 579 cases of hay fever, or a prevalence of hay fever in the United States of 8.8 per cent; but Yeh, in a sample of 6.563 Chinese, found only 226 cases, or a prevalence of hay fever in China of 3.4 per cent ${ }^{t}$. It is curious that Yeh's sample size was identical to Broder's, but the difference in prevalence of hay fever between the United States and China may be only apparent since the studies were not concurrent and there is insufficient methodological information to permit reliable comparisons.

Even so, we are left with an important puzzle: what can explain the reported absence of hay fever due to ragweed and timothy in China when both plants are found there? Is it simply a question of ragweed and timothy sensitivities not hav- ing been adequately searched for among the allergic population of China, or, more likely, are there genetic differences in sensitivities to various pollens between Chinese and Westerners? Finally, what role, if any, do psychological factors ${ }^{7.8}$ play in the prevalence of hay fever within different cultures?

\section{Institute of Botany,}

$$
\text { WANG SIYU }
$$

Academia Sinica, Beijing, PRC

Stephen A. SPONGBerg

Arnold Arboretum,

Harvard University,

Jamaica Plain, Massachusetts

Winchester, Massachusetts

Judith S. Rubenstein

Allergy Clinic,

Howard S. RubENSTEIN

University Health Services,

Harvard University,

Cambridge, Massachusetts 02139, USA

1. Yeh S-t. Immunol. Allerg. Prac. 4. 23-28 (1982)

2. Iconographia Cormophytorum Sinicorum (Institute of Botany. Academia Sinica), 4. 488 (Science Press. Beijing. PRC 1975).

3. Li Y., Chen Y.. \& Shi C. Flora Reipubliacae Popularis Sinicae, 75, 329-330 (Science Press. Beijing. 1979)

4. Rubenstein. H.S. \& Rubenstein. J.S. J. Am. med. Ass. 252 3127 (1984)

5. Iconographia Cormophytorum Sinicorum (Institute of Botany. Academia Sinica) 5. 100 (Science Press. Beiiing. 1976). . Broder I.. Higgins M.W. Mathews K.P. \& Keller J.B. J. Allerg. Clin. Immun. 54, 1(9)-110(1974).

Rubenstein H.S., King S.H. \& London. E.L. Adolescence 14. $1-18(1979)$.

Russell. M. et al. Science 225. 733-7,34 (1984)

\section{Ageing society}

SIR-In his commentary on "Prospects for an ageing population" (Nature 6 June, p.463), Jacob A. Brody pointed out the problems society faces with the marked increase in the number of elderly people and our present lack of understanding of the biology of the ageing process. Advances are, however, being made in the molecular biology of ageing that may ameliorate problems of ageing. An important discovery was the observed decrease in the rate of protein synthesis per ribosome with increasing age. The activity of most but not all enzymes per gram of tissue also decreases with age. The loss of activity of any individual enzyme appears to vary among individuals. Although we cannot yet reverse this decrease, we are in a position to overcome some of its consequences. One treatable consequence is the reduction in the biosynthesis of small organic molecules which act as coenzymes, neuro-transmitters, hormones, and so on; a list would include biopterin, carnitine, choline, coenzyme $\mathrm{Q}_{10}$, taurine and even purine and pyrimidine nucleotides and non-essential amino acids. If the body no longer produces sufficient of these materials, their lack must be overcome by including them in the diet. They become "geriatric vitamins". What is needed is research in the development of routine methods for analysing these materials in serum and urine and good methods for their synthesis or isolation so they can be used to supplement diets. Some progress has been made in this area but much needs to be done.

G. M. TENER

Department of Biochemistry,

University of British Columbia,

Vancouver, BC V6T IW5, Canada

\section{Falsifying Velikovsky}

SiR-In his review of Henry Bauer's Beyond Velikovsky, Owen Gingerich observes: "Although science cannot prove that a Velikovskian scenario is impossible, it might well prove that it did not happen"1. Although Gingerich selects Peter Huber's analysis of the Babylonian Venus tablets for this purpose, they simply are not decisive enough. Indeed, Rose and Vaughan's critique of Huber $^{2}$, to which Gingerich alludes, is stronger than he allows.

The best evidence proving Velikovsky's scenario did not happen is provided by Greenland's Dye 3 ice core ${ }^{3}$. This core is continuous and datable by counting annual layers back at least 7,200 years. Velikovsky's catastrophes should have left unequivocal markers in the ice. Not only are the expected heavy dust layers absent, but volcanic acid fallout, identified with ancient eruptions in the Velikovskian time frame, is comparable in amount to that associated with single, recent eruptions ${ }^{4}$. This is not what would be expected if catastrophes of the magnitude described by Velikovsky had actually happened ${ }^{5}$.

\section{A Utah Street,}

C. Leroy Ellenberger

St Louis, Missouri 63116, USA

1. Gingerich. O. Nature 314, 692-693 (1985)

2. Rose, L. E. \& Vaughan. R. C. Kronos X:2, 1-12 (1985)

3. Dansgaard, W. et al. Science 218, 1273-1277 (1982).

4. Hammer, C. U. et al. Nature 288, 230-235 (1980). 5. Ellenberger. C. L. Kronos X:1, 97-102 (1984).

\section{Novel microscopes}

SIR - One variety of instrument John Maddox left out when considering "New ways with microscopes" (Nature 16 May, p.177) is a scanning electron microscope using heavy ions instead of electrons. This has the advantage that it slowly "sandblasts" the object, vapourizing the constituents so they can be analysed in a mass spectrometer. It also has the advantage that the structure is slowly exposed as erosion proceeds - in fact the beam can be steered to dissect the structure at molecular scale. The heavier the ion the better, for example platinum, but molecules such as phthalocyanine are a possibility.

The snag is that heavy ions need powerful magnets to focus them. It is sad to see vast sums squandered on probably superfluous accelerators and telescopes while funds for this kind of instrument are difficult to raise.

BRENNIG JAMES

Cherry Orchard, Marlow Common, Buckinghamshire, UK 